\title{
KETERKAITAN METODE DAN MEDIA BERVARIASI DENGAN MINAT SISWA DALAM PEMBELAJARAN BIOLOGI TINGKAT SMP
}

\author{
Reisky Megawati Tammu \\ Program Studi Pendidikan Biologi, Universitas Pelita Harapan \\ E-mail: reisky.tammu@uph.edu
}

\begin{abstract}
Abstrak
Biologi merupakan salah satu bidang ilmu pengetahuan yang diajarkan pada siswa tingkat SMP melalui mata pelajaran IPA Terpadu. Sebagai bidang ilmu yang mempelajari tentang makhluk hidup dan lingkungan yang telah diciptakan secara teratur, sistematis, dan kompleks oleh Tuhan, biologi memiliki cakupan yang sangat luas dan kaya. Dalam pembelajaran biologi, metode dan media merupakan komponen penting yang dapat berpengaruh terhadap keberhasilan proses belajar mengajar serta minat siswa. Kajian ini bertujuan untuk menguraikan dan merangkum keterkaitan antara metode dan media bervariasi dengan minat siswa dalam pembelajaran biologi tingkat SMP berdasarkan studi literatur maupun hasil penelitian yang relevan. Hasil kajian menunjukkan bahwa penggunaan metode dan media bervariasi dapat memfasilitasi tercapainya tujuan pembelajaran biologi sesuai dengan karakteristik bidang ilmu \& tahap perkembangan siswa SMP, menghasilkan pembelajaran biologi yang menarik sebagai salah satu syarat untuk menumbuhkan minat siswa, dapat meningkatkan minat dan prestasi belajar siswa dalam pembelajaran biologi. Penggunaan metode dan media bervariasi dalam pembelajaran biologi tingkat SMP dapat memfasilitasi siswa yang sedang berada pada tahap formal operational thought dan pemahaman romantik untuk mengembangkan kemampuan kognitif dan minatnya dalam mengeksplorasi kekayaan dan keutuhan dari biologi sebagai suatu ilmu pengetahuan. Penggunaan metode dan media yang variatif juga akan menghasilkan proses belajar yang menarik yang membantu siswa menemukan makna dari materi yang dipelajari sehingga semakin meningkatkan minat, pemahaman konsep, dan prestasi belajar mereka dalam pembelajaran biologi.
\end{abstract}

Kata Kunci: metode, media, minat, biologi

\begin{abstract}
Biology is a science field which taught to student of junior high school level through Integrated Science subject. As a science field that studies about living things and environment which have been created regularly, systematically, and complexly by God, biology has a very wide and rich coverage. In learning biology, methods and media are important components that can influence the success of teaching and learning process, and student interest. This study aims to describe and summarize the interrelationships between methods and media varies with student interest in biology's learning of junior high school based on literature studies and relevant research results. The results of the study indicate that the use of varied methods and media can facilitate the achievement of biology's learning objectives in accordance with the characteristics of the science field and the stage of development of junior high school students, can create an interesting biological learning as one of the requirements to cultivate student interest, can increase student interest and their achievement in biology. The application of varied methods and media in the junior-level biology learning can facilitate students who are in the formal stage of operational thought and romantic understanding to develop their cognitive abilities and interests in exploring the richness and oneness of biology as a science. It will also produce an interesting learning process which can help students discover the meaning of the material learned so that it will increase their interest, concept's understanding, and learning achievements in biology.
\end{abstract}

Keywords: method, media, interest, biology 


\section{PENDAHULUAN}

Biologi merupakan cabang ilmu pengetahuan yang mempelajari tentang makhluk hidup dan lingkungannya. Pada tingkat SD dan SMP, pembelajaran biologi digabungkan dengan fisika dan kimia dalam mata pelajaran IPA Terpadu. (Depdiknas 2003) menyatakan bahwa biologi merupakan wahana untuk meningkatkan pengetahuan, keterampilan, sikap, nilai dan tanggung jawab sebagai seorang warga negara yang beriman dan bertakwa kepada Tuhan Yang Maha Esa sesuai ajaran agama yang dianutnya, serta bertanggung jawab terhadap lingkungan, masyarakat, bangsa dan negara. Dalam mempelajari biologi, para siswa akan menyadari pribadi dan peranannya sebagai penjaga bumi, memelihara kesehatan tubuh dan lingkungan, mengembangkan gaya hidup yang melayani, menjaga keharmonisan antara makhluk hidup, serta bertanggung jawab dengan masalah sosial yang mempunyai unsur ilmiah (Van Brummelen 2006). Dengan demikian, pembelajaran biologi memiliki tujuan yang sangat penting untuk menuntun siswa semakin beriman kepada Tuhan dan menyadari keberadaan, peran dan tanggung jawab mereka terhadap sesama manusia serta makhluk hidup lainnya dalam lingkungan masyakat, berbangsa dan bernegara.

Pembelajaran biologi sebagai bagian dari pendidikan sains memiliki tiga komponen utama, yaitu produk, proses dan sikap (Brahim 2007). Produk sains dapat berupa konsep, generalisasi dan teori. Proses sains berupa langkah-langkah penyelidikan masalah, observasi, dan menguji hipotesis. Sedangkan, sikap sains meliputi ketelitian, kejujuran, kepedulian, kemampuan membuat keputusan dan sebagainya. Dari komponen-komponen di atas, dapat dilihat bahwa pembelajaran biologi bukan hanya menekankan teori tetapi juga praktek yang membutuhkan keterampilan proses dan sikap dalam penerapan di kehidupan sehari-hari. Hal ini sejalan dengan pernyataan (Depdiknas 2003) bahwa biologi bukan hanya penguasaan kumpulan pengetahuan yang berupa fakta-fakta, konsep-konsep, prinsip-prinsip saja tetapi juga merupakan suatu proses penemuan.

Biologi memiliki cakupan materi yang sangat luas dan kaya karena mempelajari tentang kehidupan yang telah diciptakan secara teratur, sistematis, dan kompleks oleh Tuhan. Hal ini didasarkan pada pengertian biologi yang dikemukakan oleh (Campbell et al. 2002), yaitu pengejawantahan ilmiah dari kecenderungan manusia yang merasa mempunyai hubungan dan tertarik pada semua bentuk kehidupan dengan ruang lingkup yang sangat luas. Dalam ruang lingkup produk yang luas itu, pembelajaran biologi tetap menekankan pada proses dan sikap melalui praktek atau penerapan dalam kehidupan. Hal ini menunjukkan bahwa biologi cukup kompleks untuk dipelajari. Sebagai contoh dari hal di atas yaitu tema Sistem Pernapasan pada manusia. Pada bab ini, siswa tingkat SMP akan mempelajari teori mengenai pengertian pernapasan, perbedaan pernapasan dengan respirasi, macam-macam pernapasan, alat-alat pernapasan, mekanisme pernapasan, mekanisme pertukaran gas, volume udara pernapasan, serta penyakit pada sistem pernapasan. Kemudian, dalam hal penerapan siswa juga perlu melakukan beberapa praktikum untuk meningkatkan pemahaman, keterampilan dan sikap ilmiah, seperti mengamati mekanisme pernapasan, perbedaan kadar udara ekspirasi dengan inspirasi, dan kapasitas vital paruparu. Ditambah lagi dengan adanya kosakata yang harus dikenali yaitu istilah dalam bahasa ilmiah yang berhubungan dengan tema pernapasan, contohnya cavum nasalis (rongga hidung), epiglotis (katup), faring (tekak), pleura (selaput paru-paru), dan pulmo (paru-paru).

Kompleksitas biologi dalam pelajaran IPA Terpadu di tingkat SMP jika diajarkan dengan menggunakan strategi pembelajaran yang kurang tepat tentunya akan membuat siswa kurang berminat dan kompetensi yang diharapkan akan sulit dicapai. Riset membuktikan bahwa sebagian besar cara guru mengajar di kelas masih tetap menggunakan kebiasaan yang lama atau lebih dominan menggunakan metode ceramah-ekspositori sehingga siswa cenderung resisten, penonton, dan pasif (Suherman 2008). Dalam hal ini, metode dan media merupakan komponen penting yang akan berpengaruh terhadap keberhasilan proses belajar mengajar serta minat siswa dalam pembelajaran biologi. Oleh sebab itu, kajian ini bertujuan untuk menguraikan dan merangkum keterkaitan antara metode dan media bervariasi dengan minat siswa dalam pembelajaran biologi tingkat SMP berdasarkan studi literatur maupun hasil penelitian yang relevan.

\section{METODE}

Metode penelitian yang digunakan dalam penelitian ini adalah metode penelitian kepustakaan (Library Research). Penelitian kepustakaan adalah salah satu metode penelitian kualitatif yang tempat penelitiannya dilakukan di pustaka dengan dokumen, arsip, dan jenis dokumen lainnya sebagai bahan penelitiannya (Prastowo 2012). Selanjutnya, (Zed 2008) berpendapat bahwa metode kepustakaan bukan hanya sekedar urusan membaca dan mencatat literatur atau buku-buku sebagaimana yang sering dipahami banyak orang selama ini. Metode kepustakaan adalah serangkaian kegiatan yang berkenaan dengan metode pengumpulan data 
pustaka, membaca, dan mencatat serta mengelolah bahan penelitian.

\section{PEMBAHASAN}

\section{Tinjauan Mengenai Minat Siswa dalam Pembelajaran Konsep mengenai minat}

Menurut (Djaali 2007), minat adalah penerimaan akan hubungan diri dengan sesuatu di luar diri atau lingkungan yang berupa afeksi, kesadaran sampai pilihan nilai, pengerahan perasaan, seleksi, dan kecenderungan hati yang dapat dimanifestasikan melalui partisipasi dalam suatu aktivitas. Sejalan pendapat di atas, (Slameto 2003) menyatakan minat bahwa adalah suatu rasa lebih suka dan rasa ketertarikan pada suatu hal atau aktivitas tertentu tanpa paksaan atau ada orang lain yang menyuruh. Menurut Gordon seperti yang dikutip oleh (Sanjaya 2006), minat adalah kecenderungan seseorang untuk melakukan suatu tindakan atau perbuatan, misalnya minat untuk mempelajari atau memperdalam materi pelajaran. Menurut (Hurlock 2000), minat merupakan sumber motivasi yang mendorong orang untuk melakukan apa yang mereka inginkan ketika bebas memilih

Menurut Arbor seperti yang dikutip oleh (Kusmiyati 2007), minat mengandung unsur kognisi, emosi dan konasi. Unsur kognisi berarti pengetahuan dan informasi mengenai objek yang dituju. Unsur emosi yaitu adanya perasaan senang dalam partisipasi ataupun pengalaman. Sedangkan, unsur konasi merupakan kelanjutan unsur kognisi dan emosi yang diwujudkan dalam bentuk kemauan atau hasrat untuk melakukan suatu kegiatan. Sejalan dengan pendapat di atas, (Hurlock 2000), menyatakan minat terdiri atas dua aspek yaitu sebagai berikut: (a) aspek kognitif didasarkan pada konsep yang dikembangkan siswa mengenai bidang yang berkaitan dengan minat, dan (b) aspek afektif, merupakan konsep yang membangun aspek kognitif dinyatakan dalam sikap terhadap yang ditimbulkan minat.

Berdasarkan uraian di atas, maka terdapat beberapa konsep penting mengenai minat. Pertama, minat berasal dari dalam diri siswa yang berupa kecenderungan hati atau ketertarikan. Kedua, minat dapat dipengaruhi oleh sesuatu di luar diri atau lingkungan. Ketiga, minat dapat diekspresikan melalui tindakan ataupun aktivitas.

\section{Peran minat siswa dalam pembelajaran}

Dalam pembelajaran, minat memegang peranan yang penting. Minat dapat mempengaruhi keberhasilan siswa dalam menguasai suatu pelajaran. Hal ini sesuai dengan pendapat (Djaali 2007), bahwa minat yang telah disadari terhadap bidang pembelajaran, mungkin sekali akan menjaga pikiran siswa sehingga dia berhasil menguasai pelajarannya, sebaliknya prestasi yang berhasil akan menambah minat siswa sehingga bisa berlanjut sepanjang hidupnya. Hal ini berarti terdapat hubungan timbal balik antara minat dan keberhasilan pembelajaran. Minat akan menunjang keberhasilan pembelajaran siswa sedangkan keberhasilan akan semakin memperkuat minat siswa terhadap suatu pembelajaran. Hal ini sejalan dengan pendapat (Hurlock 2000), bahwa minat lebih bersifat tetap atau persistent karena minat memuaskan kebutuhan penting dalam hidup seseorang, dan akan menjadi semakin kuat jika semakin sering diekspresikan dalam sebuah kegiatan.

Minat sangat berkaitan dengan motivasi belajar siswa. Hal ini disebabkan karena pada dasarnya proses motivasi amat ditentukan oleh minat (interest) dan atribusi (attribution), dimana minat sangat bersifat pribadi atau personal dan bersumber dari diri sendiri (Pannen et al. 2001). Hal ini berarti bahwa minat siswa mempengaruhi motivasi belajarnya dalam suatu pembelajaran. Misalnya, siswa yang berminat pada hal-hal yang berkaitan dengan tumbuhan dan hewan, maka kemungkinan ia memiliki motivasi belajar yang lebih tinggi dalam pembelajaran IPA Terpadu. Siswa yang berminat terhadap suatu pelajaran akan terdorong untuk tekun belajar. Mengingat pentingnya minat dalam pembelajaran tersebut, maka guru perlu memperhatikan dan berupaya menumbuhkan minat belajar siswa.

(Depdiknas 2007) menyatakan, pengalaman di negara lain menunjukkan bahwa minat dan prestasi siswa dalam bidang sains mengalami meningkat secara drastis ketika: (1) mereka dibantu untuk membangun keterkaitan antara pengetahuan baru dengan pengalaman atau pengetahuan lain yang telah dikuasai; (2) mereka diajarkan bagaimana mempelajari konsep, dan penggunaan konsep tersebut di luar kelas; (3) mereka diberikan kesempatan untuk bekerja secara bersama-sama (cooperative). Menurut Bernard, minat tidak timbul secara spontan atau tiba-tiba melainkan mucul sebagai akibat dari partisipasi, pengalaman, kebiasaan pada waktu belajar maupun bekerja (Sardiman 2001). Adanya minat akan membuat siswa lebih giat belajar sehingga pada akhirnya akan memiliki prestasi yang baik (Rahmat 2009). Kegiatan siswa merupakan kunci dari minat mereka sehingga guru-guru dapat mengamati siswa-siswa yang sangat bersemangat, antusias dan memberi perhatian yang tinggi selama pelajaran berlangsung sebagai salah satu cara untuk mengetahui dan mengukur minat siswa (Djiwandono 2006). Menurut Super dan Sumartono seperti yang dikutip oleh (Rahmat 2009), terdapat empat cara untuk mengetahui minat yaitu: (1) melihat kenyataan apakah seseorang senang atau tidak senang terhadap suatu objek, aktivitas atau pekerjaan, (2) melihat dan mengobservasi partisipasi seseorang dalam suatu aktivitas atau pekerjaan, (3) menggunakan tes objektif, (4) mengukur atau melihat jawaban-jawaban seseorang dari sejumlah pertanyaan tentang aktivitas yang disenangi.

\section{Tinjauan Mengenai Metode dan Media Pembelajaran Metode Pembelajaran Pengertian metode pembelajaran}

Menurut Heinich seperti yang dikutip oleh (Yamin \& Ansari 2008), metode adalah prosedur yang sengaja dirancang untuk membantu siswa belajar dengan lebih baik guna mencapai tujuan pembelajaran yang ditetapkan. 
Kedudukan metode dalam belajar mengajar yaitu sebagai alat motivasi intrinsik, sebagai strategi pengajaran, dan sebagai alat untuk mencapai tujuan (Djamarah \& Zain 2006). Metode merupakan bagian integral dalam proses belajar mengajar yang berperan penting bagi guru maupun siswa. Bagi siswa, metode pembelajaran membantu mereka dalam memahami pelajaran yang disampaikan. Bagi guru, metode pembelajaran dapat memfasilitasi mereka untuk menyampaikan pengetahuan pada siswa.

\section{Jenis-jenis metode pembelajaran}

Beberapa jenis metode pembelajaran menurut (Djamarah \& Zain 2006) yaitu sebagai berikut:

\section{Metode ceramah}

Metode ceramah adalah metode penyampaian materi pelajaran secara lisan. Dalam pelajaran biologi, metode ini banyak digunakan untuk menjelaskan konsep yang abstrak, kompleks, dan sukar ditampilkan dalam bentuk kegiatan (Nuryani 2005). Kelebihan metode ceramah yaitu guru mudah menguasai kelas, dapat diikuti oleh jumlah siswa yang besar, dan mudah dipersiapkan. Namun, metode ini cepat membosankan, merugikan siswa yang visual, dan cenderung menyebabkan siswa pasif.

2. Metode tanya jawab

Metode ini menggunakan pertanyaan-pertanyaan yang telah direncanakan sebelumnya berdasarkan konsep yang ingin dipahami oleh siswa (Nuryani 2005). Metode ini dapat menarik dan memusatkan perhatian siswa, mengembangkan daya pikir dan menjadi pendorong untuk penelusuran lebih lanjut pada berbagai sumber belajar. Namun, metode ini membutuhkan waktu dan persiapan dalam menyusun pertanyaan yang dapat mengembangkan daya pikir siswa serta waktu sering terbuang jika pertanyaan tidak terjawab oleh siswa.

3. Metode demonstrasi

Metode demonstasi adalah cara penyajian materi pelajaran dengan memeragakan atau mempertunjukkan kepada siswa mengenai suatu proses, situasi, atau benda tertentu yang sedang dipelajari baik asli maupun tiruan, disertai penjelasan lisan. Metode ini dapat membuat pelajaran menjadi lebih jelas dan konkret sehingga siswa menjadi lebih mudah mengerti konsep yang diajarkan. Hal ini sesuai dengan tujuan metode demostrasi yaitu memperjelas pengertian konsep dan memperlihatkan cara melakukan atau proses terjadinya sesuatu (Sutikno 2009). Peragaan tersebut dapat dilakukan oleh guru maupun siswa sendiri.

4. Metode diskusi

Metode diskusi adalah cara pembelajaran dengan memunculkan masalah sehingga terjadi pertukaran ide atau pendapat untuk memperoleh persamaan pendapat ataupun suatu kesimpulan jawaban (Nuryani 2005). Diskusi dapat dibedakan atas dua yaitu diskusi kelompok dan diskusi kelas. Kelebihan metode ini adalah merangsang keberanian dan kreativitas dalam mengemukakan pendapat, melatih siswa berpikir kritis dan menghargai pendapat orang lain. Namun kelemahannya adalah pembicaraan sering didominasi orang tertentu dan terkadang meluas atau mengambang.

5. Metode eksperimen

Metode eksperimen adalah cara penyajian materi pelajaran dengan menggunakan percobaan. Dalam eksperimen, siswa melakukan kegiatan pengendalian variabel, pengamatan, penggunaan alat-alat praktikum. Kelebihan metode ini yaitu siswa dapat semakin mengerti dan meyakini konsep yang telah diajarkan, memperkaya pengalaman dan keterampilan, dan mengembangkan sikap ilmiah (Nuryani 2005). Namun, metode ini terkadang memerlukan banyak persiapan terkadang ada peralatan yang sulit diperoleh.

6. Metode permainan

Metode permainan merupakan metode penyajian materi pelajaran dengan cara yang menyenangkan, santai, namun serius. Metode ini digunakan untuk mencapai tujuan belajar yang telah ditetapkan secara efisien dan efektif dalam suasana gembira meskipun membahas materi yang sulit atau berat.

\section{Media Pembelajaran \\ Pengertian media pembelajaran}

Kata media berasal dari Bahasa Latin, dan merupakan bentuk jamak dari medium yang secara harafiah berarti pengantar atau perantara pesan dari pengirim kepada penerima (Sadiman et al. 2005). Briggs seperti yang dikutip oleh (Prastati \& Irawan 2001), menyatakan media adalah sarana fisik untuk menyampaikan isi/materi pembelajaran. Menurut (Djamarah \& Zain 2006), media adalah alat bantu apa saja yang dapat dijadikan sebagai penyalur pesan guna mencapai tujuan pengajaran.

Media pembelajaran merupakan segala jenis sarana yang dapat diindra dan digunakan dalam proses belajar mengajar untuk meningkatkan efektivitas dan efisiensi pencapaian tujuan pembelajaran (Nuryani 2005). Media pembelajaran adalah segala sesuatu yang dapat menyampaikan dan menyalurkan pesan dari sumber secara terencana sehingga tercipta lingkungan belajar yang kondusif dimana penerimanya dapat melakukan proses pembelajaran secara efektif dan efisien (Munadi 2008). Uraian di atas menunjukkan bahwa media pembelajaran merupakan perantara ataupun penyalur pesan yang digunakan dalam proses pembelajaran guna mencapai tujuan yang telah direncanakan sebelumnya. 
Media pembelajaran mempunyai fungsi yang penting dalam pembelajaran. Menurut (Nuryani 2005), fungsi media pembelajaran yaitu untuk memperjelas informasi yang diberikan secara verbal, meningkatkan perhatian, meningkatkan efektifitas dan efisiensi penyampaian materi, menambah variasi penyajian materi, memberikan pengalaman konkret, dan meningkatkan ketertarikan ataupun keingintahuan siswa, memberikan stimulus dan mendorong respon siswa dalam pembelajaran.

\section{Jenis-jenis media pembelajaran}

Dalam proses pembelajaran media dapat dikelompokkan menjadi empat kelompok besar berdasarkan indera yang terlibat yaitu (Munadi 2008):

1. Audio

Media audio adalah media yang hanya melibatkan indera pendengaran yang dapat terdiri atas pesan verbal (kata-kata atau bahasa lisan) dan pesan nonverbal (bunyi-bunyian dan vokalisasi seperti gerutuan, gumam, musik dan sebagainya). Kelebihan-kelebihan media audio yaitu: (1) mampu mengatasi ruang dan waktu, (2) mengembangkan imajinasi pendengar, (3) memusatkan perhatian siswa pada penggunaan kata dan bunyi, dan (4) mampu mempengaruhi suasana dan perilaku siswa. Jenis-jenis media audio yaitu radio, $\mathrm{CD}$, cassette recorder, dan sebagainya.

2. Visual

Media visual adalah media yang melibatkan indera penglihatan. Terdapat dua jenis pesan yang dimuat dalam media visual yaitu pesan verbal yang berupa kata-kata dalam bentuk tulisan, dan pesan non-verbal yang berupa simbol-simbol. Karakteristik media visual yaitu pesan visual, penyalur pesan visual dan benda asli dan tiruan. Contohnya gambar, torso, miniatur dan sebagainya.

3. Audiovisual

Media audiovisual adalah media yang mempunyai unsur suara dan unsur gambar. Media ini dibagi menjadi dua macam yaitu audiovisual diam dan audiovisual gerak. Audiovisual diam adalah media yang menampilkan suara dan gambar diam seperti film bingkai suara, film rangkai suara dan cetak suara, sedangkan audiovisual gerak dapat menampilkan unsur suara dan gambar yang bergerak seperti film suara dan video (Djamarah \& Zain 2006).

4. Multimedia

Multimedia adalah media yang mampu melibatkan banyak indera dan organ tubuh selama proses pembelajaran berlangsung. Multimedia dapat dibedakan atas dua yaitu multimedia berbasis komputer dan pengalaman langsung. Bentuk pemanfaatan multimedia berbasis komputer yaitu multimedia presentasi, program multimedia interaktif, video pembelajaran, internet dan e-learning.

Menurut (Nuryani 2005) beberapa jenis media pembelajaran yang sering digunakan dalam pembelajaran biologi adalah sebagai berikut: (a) media asli hidup dan mati, seperti akuarium, insektarium, herbarium, awetan dalam botol; (b) media asli benda dan tiruan, seperti batuan mineral, model penampang batang, torso tubuh manusia, model atom, model DNA, papan tulis, maket, dan papan tempel; (c) media grafis, seperti bagan, bagan, grafik, poster, gambar, foto; (d) media audio, seperti radio, tape recorder;; (e) media audio-visual, seperti televisi, video, film suara, slide suara; dan (f) media cetak, seperti buku cetak, koran, majalah.

\section{Pembelajaran Biologi Tingkat SMP}

Siswa yang berada pada jenjang SMP pada umumnya berusia sekitar 13 sampai 15 tahun. Dari segi psikologis, pada usia tersebut mereka telah memasuki tahap pemikiran operasional formal (formal operational thought) menurut teori kognitif Piaget. Pada tahap ini mereka sudah bisa berpikir abstrak dan hipotesis, sistematis, mampu memikirkan semua kemungkinan untuk memecahkan permasalahan, dan perkembangan kognitif mereka mencapai tingkatan tertinggi pada keseimbangan dalam hubungannya dengan lingkungan (Desmita 2005). Hal ini sejalan dengan pendapat (Santrock 2003), yang menyatakan bahwa pada tahap formal operational thought, individu bergerak melebihi dunia pengalaman aktual dan konkrit, berpikir lebih abstrak dan logis sehingga dalam memecahkan masalah mereka lebih sistematis, dapat mengembangkan hipotesis mengapa sesuatu terjadi seperti itu, dan kemudian menguji hipotesis secara deduktif.

Selain meninjau dari sudut perkembangan kognitif menurut teori Piaget, perkembangan siswa juga akan ditinjau dari tahap pemahaman menurut teori Kieran Egan. Ada tiga tahap pemahaman menurut Egan yaitu pemahaman mitos pada usia 0-8 tahun, romantik pada usia 8-15 tahun dan filosofi pada usia 15-19 tahun (Van Brummelen 2006). Pada jenjang SMP, siswa telah memasuki tahap pemahaman romantik. Menurut teori Kieran Egan, dalam tahap ini, para siswa masih berminat pada penyampaian berbentuk naratif atau cerita, namun lebih memilih tema petualangan, imajinasi, idealisme, antusias menjelajahi dunia dan merasakan pengalaman di dalamnya, serta berminat terhadap fakta disertai penjelasan tentang bagaimana dan mengapa hal-hal bisa terjadi.

Berdasarkan penjabaran di atas, terlihat bahwa perkembangan kognitif cukup mempengaruhi minat siswa. Pada jenjang SMP, siswa sudah bisa berpikir abstrak, hipotesis, logis dan sistematis. Hal ini membuat 
mereka akan lebih berminat pada pembelajaran yang memfasilitasi kemampuan yang mereka miliki pada usianya. Mereka berminat pada petualangan atau mencari tahu fakta dan bagaimana hal-hal bisa terjadi karena mereka sudah memiliki kemampuan untuk berpikir hipotesis dan sistematis.

Biologi merupakan salah satu bagian dari mata pelajaran IPA Terpadu yang diajarkan di SMP. Menurut (Nuryani 2005), pada jenjang SMP terdapat tiga misi utama dari pengajaran Biologi, sebagai berikut: (1) aspek empiris, belajar biologi berarti berupaya mengenali proses kehidupan nyata di lingkungan (purpose in empirical evidence); (2) aspek evaluasi, belajar biologi adalah berupaya mengenali diri sendiri sebagai makhluk (purpose in human institution); (3) aspek sintas, belajar biologi diharapkan bermanfaat untuk peningkatan kualitas serta kelulushidupan manusia dan lingkungannya (purpose in human life). Sejalan dengan misi tersebut, Permendikbud RI nomor 22 tahun 2016 menyatakan bahwa pada tingkat SMP, tujuan kurikulum IPA Terpadu mencakup empat kompetensi sebagai berikut: (1) kompetensi sikap spiritual yaitu menghargai dan menghayati ajaran agama yang dianutnya; (2) sikap sosial yaitu menunjukkan perilaku jujur, disiplin, tanggung jawab, peduli (toleransi, gotong royong), santun, dan percaya diri, dalam berinteraksi secara efektif dengan lingkungan sosial dan alam dalam jangkauan pergaulan dan keberadaannya; (3) pengetahuan yaitu memahami pengetahuan baik faktual, konseptual maupun prosedural berdasarkan rasa ingin tahunya tentang ilmu pengetahuan, teknologi, seni, budaya terkait fenomena dan kejadian tampak mata; dan (4) keterampilan yaitu mencoba, mengolah, dan menyaji dalam ranah konkret seperti menggunakan, mengurai, merangkai, memodifikasi, dan membuat, serta ranah abstrak yang terdiri atas menulis, membaca, menghitung, menggambar, dan mengarang sesuai dengan yang dipelajari di sekolah dan sumber lain yang sama dalam sudut pandang/teori (Depdikbud 2016). Kompetensi-kompetensi inilah yang perlu dicapai oleh siswa melalui proses pembelajaran biologi dalam mata pelajaran IPA Terpadu yang dilakukan di tingkat SMP.

Berdasarkan penjabaran di atas, maka dapat terlihat bahwa sebenarnya ditinjau karakter bidang ilmu maupun misi dan tujuan kurikulumnya, biologi dan pembelajarannya sangat sesuai atau relevan dengan perkembangan siswa SMP yang berada pada tahap formal operational thought dan pemahaman romantik. Oleh sebab itu, peran guru sangat dibutuhkan merancang pembelajaran termasuk metode dan media yang akan digunakan dengan memperhatikan karakteristik perkembangan siswa dan bidang ilmu yang terkait.

\section{Kaitan Metode dan Media Bervariasi dengan Minat Siswa dalam Pembelajaran Biologi Tingkat SMP}

Metode dan media merupakan komponen penting dalam pembelajaran. Dalam penggunaannya di kelas, metode dan media saling berhubungan dan saling menunjang untuk membantu guru maupun siswa mencapai tujuan pembelajaran. Menurut Surakhmad seperti yang dikutip oleh (Djamarah \& Zain 2006), pemilihan metode dipengaruhi oleh beberapa faktor yaitu anak didik, tujuan, situasi, fasilitas dan guru. Sejalan dengan pemilihan metode, terdapat juga beberapa faktor dalam pemilihan media pembelajaran yaitu komponen tujuan, materi pembelajaran, pendekatan/metode, evaluasi dan siswa (Nuryani 2005). Dengan demikian, pemilihan dan penggunaan metode harus disesuaikan dan disertai dengan media pembelajaran, begitu pun sebaliknya. Keterkaitan antara metode dan media bervariasi dengan minat siswa dalam pembelajaran biologi SMP dapat diuraikan secara bertahap sebagai berikut:

\section{a) Penggunaan metode dan media bervariasi dapat memfasilitasi tercapainya tujuan pembelajaran biologi sesuai dengan karakteristik bidang ilmu \& tahap perkembangan siswa SMP.}

Dalam rangka mencapai tujuan pembelajaran biologi seperti yang telah dibahas sebelumnya, maka metode dan media pembelajaran yang bervariasi perlu digunakan di kelas. Menurut KBBI bervariasi berarti memiliki lebih dari satu jenis, rupa atau bentuk, ataupun ada selingan. Dalam pembahasan ini, metode dan media bervariasi berarti tidak hanya menggunakan satu metode atau satu media selama pembelajaran (monoton) dalam periode yang lama, melainkan menerapkan lebih dari satu metode, atau lebih dari satu media, ataupun mengkombinasikan metode dan media tertentu yang berbeda dengan biasanya dalam pembelajaran.

Metode dan media bervariasi yang digunakan dalam pembelajaran biologi dapat memfasilitasi siswa untuk mengeksplorasi kekayaan dan keutuhan dari biologi. Hal ini akan memberikan pengalaman belajar yang menarik terutama bagi siswa SMP yang sedang berada dalam perkembangan kognitif tahap formal operational thought Piaget dan tahap pemahaman romatik menurut Kieran Egan. Sebagai ilmu yang mempelajari tentang kehidupan yang telah diciptakan secara teratur, sistematis, dan kompleks oleh Tuhan, biologi memiliki cakupan bahan kajian yang sangat kaya, luas dan beragam. Selain itu, biologi bukan hanya berfokus pada penyajian teori tetapi membutuhkan praktik dan penerapan karena sangat dekat dan relevan dengan kehidupan siswa sehari-hari. Hal ini sangat mendukung perkembangan kemampuan kognitif siswa SMP dan turut mempengaruhi minat mereka. Sesuai pembahasan sebelumnya, dalam tahap ini mereka akan 
mulai memikirkan berbagai konsep secara sistematis dan berpikir hipotesis sehingga lebih berminat terhadap fakta disertai penjelasan tentang bagaimana dan mengapa halhal yang yang sering mereka amati dalam kehidupan sehari-hari bisa terjadi. Terkait dengan hal tersebut, (Depdiknas 2007) menyatakan bahwa pembelajaran biologi perlu menekankan pada pemberian pengalaman secara langsung kepada siswa untuk membantu mereka mengembangkan sejumlah keterampilan proses yang meliputi keterampilan mengamati, mengajukan hipotesis, menggunakan alat dan bahan secara benar dengan pertimbangan keselamatan kerja, mengajukan pertanyaan, menggolongkan, menafsirkan data dan menyampaikan hasil temuan secara beragam, menggali dan memilah informasi faktual yang relevan untuk menguji gagasangagasan atau memecahkan masalah sehingga akhirnya mereka mampu menjelajahi dan memahami kehidupan serta alam sekitarnya. Menurut (Yamin \& Ansari 2008), pengalaman langsung tersebut dapat diperoleh oleh siswa melalui pengalaman inderawi yang memungkinkan mereka untuk memperoleh informasi dari melihat, mendengar, meraba, mencicipi dan mencium. Dengan demikian, penggunaan metode dan media bervariasi dalam pembelajaran biologi tingkat SMP dapat memfasilitasi siswa yang sedang berada pada tahap formal operational thought dan pemahaman romantik untuk mengembangkan kemampuan kognitif dan minatnya dalam mengeksplorasi kekayaan dan keutuhan dari biologi sebagai suatu ilmu pengetahuan. Hal inilah yang akan mendorong tercapainya tujuan pembelajaran biologi.

\section{b) Penggunaan metode dan media bervariasi dapat menghasilkan pembelajaran biologi yang menarik sebagai salah satu syarat untuk menumbuhkan minat siswa.}

Keberhasilan siswa dalam pembelajaran biologi tingkat SMP bukan hanya dipengaruhi oleh perkembangan kemampuan kognitif tetapi juga minat mereka. Siswa perlu memiliki minat terhadap pembelajaran biologi itu sendiri. Hal ini didukung oleh Dalyono seperti yang dikutip oleh (Susilonuringsih 2006), bahwa minat adalah salah satu faktor intern yang mempengaruhi belajar siswa. Sebagai bidang ilmu yang mempelajari kehidupan dengan cakupan yang kaya, beragam, dan luas, biologi seharusnya diminati oleh siswa SMP karena banyak teori, fenomena, fakta, serta konsep dalam kehidupan sehari-hari yang bisa mereka eksplorasi sesuai dengan berkembangnya kemampuan mereka untuk berpikir sistematis, logis, dan hipotesis pada tahap formal operational thought dan pemahaman romantik. Minat tersebut diperlukan untuk mendorong siswa lebih perhatian terhadap pelajaran, lebih mudah dalam memahami materi, lebih aktif dalam pembelajaran sehingga kompetensi siswa yang diharapkan dapat tercapai. Hal ini berarti minat memiliki pengaruh terhadap prestasi belajar siswa. Hasil penelitian (Muldayanti 2013) menunjukkan bahwa terdapat perbedaan minat belajar tinggi dan rendah terhadap prestasi belajar biologi, sehingga minat belajar yang tinggi akan mendapat prestasi belajar tinggi juga.

Penggunaan metode dan media yang variatif akan menghasilkan proses belajar yang menarik sebagai salah satu syarat untuk menumbuhkan minat siswa dalam pembelajaran biologi. Hal ini sesuai dengan pernyataan Manurung dan Matutina seperti yang dikutip oleh (Rahmat 2009) bahwa beberapa syarat untuk membangkitkan minat yaitu: (1) belajar harus menarik perhatian; (2) objek atau keadaan yang menarik akan menimbulkan belajar; (3) para siswa dilatih bekerja sendiri atau diberikan kesempatan turut aktif selama pengajaran berlangsung; (4) semua kegiatan harus kontras sehingga dapat menimbulkan minat untuk mengetahui lebih lanjut. Hal ini didukung oleh pendapat (Djamarah \& Zain 2006)bahwa guru sebaiknya menggunakan metode yang bervariasi agar jalannya pengajaran tidak membosankan tetapi menarik perhatian siswa. (Munadi 2008) juga menyatakan bahwa penggunaan berbagai media di dalam kelas berkaitan dengan fungsi psikologis yang terdiri atas atensi, afektif, kognitif, imajinatif dan motivasi. Metode dapat dipadukan dengan media yang tepat untuk menarik perhatian siswa dan mengembangkan minat mereka, misalnya metode tanya jawab dengan media gambar di awal pembelajaran. Guru dapat memberikan pertanyaan yang tepat sesuai gambar untuk membuat siswa tertarik dan ingin tahu topik bahasan yang akan dipelajari. Hal ini sesuai dengan pendapat (Uzman 2007) yang menyatakan bahwa pemberian pertanyaan secara tepat akan memberikan dampak positif yakni membangkitkan minat dan rasa ingin tahu siswa tentang sesuatu yang sedang dibahas dan meningkatkan partisipasi.

Penggunaan metode dan media bervariasi telah terbukti dapat meningkatkan minat siswa dalam pembelajaran biologi tingkat SMP. Hasil penelitian (Setiawan \& Napitupulu 2014) menunjukkan bahwa penerapan metode Group Investigation dengan menggunakan media komik dapat meningkatkan minat belajar biologi siswa dari $72,75 \%$ saat pra siklus menjadi $82,47 \%$ pada siklus II berdasarkan indikator partisipasi, perhatian, dan sebagainya. (Rizky et al. 2015) juga melaporkan bahwa penerapan metode eksperimen dengan menggunakan media asli tumbuhan dapat meningkatkan hasil belajar siswa dengan rata-rata nilai kognitif 85,42 dan rata-rata aktivitas mencapai 90,63 pada siklus II pada pokok bahasan Klasifikasi Makhluk Hidup di kelas VIIA SMPN Maesan. Sebagaimana telah dibahas sebelumnya, 
aktivitas siswa menunjukkan minat mereka. Semakin tinggi aktivitas siswa dalam suatu pembelajaran menunjukkan adanya peningkatan minat.

\section{c) Penggunaan metode dan media bervariasi dapat meningkatkan minat, pemahaman konsep, dan prestasi belajar siswa dalam pembelajaran biologi.}

Metode dan media bervariasi dapat digunakan guru untuk membantu siswa menemukan makna dari materi yang dipelajari dalam kehidupan sehari-hari sehingga semakin meningkatkan minat mereka terhadap pembelajaran biologi. Hal ini sesuai dengan pendapat (Slameto 2003) bahwa mengembangkan dan meningkatkan minat siswa terhadap sesuatu pada dasarnya membantu siswa melihat bagaimana hubungan antara materi yang dipelajarinya dengan dirinya sendiri sebagai individu. Meningkatkan dan mengembangkan minat siswa dalam pembelajaran biologi berarti membantu siswa untuk memahami hubungan antara belajar biologi dengan dirinya sebagai individu yang merupakan bagian dari alam dan lingkungan tempat ia tinggal. Hal tersebut dapat dicapai dengan diterapkannya metode dan media bervariasi dalam pembelajaran biologi, sesuai dengan pendapat (Suciati \& Irawan 2001) yang menyatakan bahwa strategi yang dapat merangsang minat dan perhatian siswa secara aplikatif di dalam kelas, antara lain: (1) menggunakan metode penyampaian yang bervariasi, misalnya penjelasan, diskusi, role play, simulasi, curah pendapat, demonstrasi, studi kasus; (2) menggunakan media untuk memperlengkapi penyampaian materi misalnya film, video, gambar, alat peraga, dan sebagainya; (3) membangun suasana menyenangkan misalnya humor pada saat yang tepat; (4) menggunakan peristiwa nyata, anekdot dan contoh-contoh untuk memperjelas konsep yang diutarakan; serta (5) menggunakan teknik bertanya yang melibatkan siswa.

Sebagaimana telah dijelaskan sebelumnya bahwa minat siswa akan mempengaruhi hasil belajar mereka. Penerapan metode dan media bervasiasi bukan hanya meningkatkan minat siswa, tetapi juga dapat membantu siswa memahami konsep materi sehingga prestasi atau hasil belajarnya semakin meningkat. Hasil penelitian (Setiawan \& Napitupulu 2014) menunjukkan bahwa penggunaan media flipchart yang disertai dengan penerapan metode diskusi, tanya jawab dan ekspositoris dalam pembelajaran biologi dapat meningkatkan penguasaan materi siswa pada pokok bahasan Pertumbuhan dan Perkembangan di kelas VIII SMP Negeri 2 Teluk Mengkudu sebesar 85,2\% dari prasiklus hingga siklus II. Hal ini sejalan dengan hasil penelitian Dodo dan Oetpah (2016) yang menunjukkan bahwa penggunaan media animasi yang disertai dengan penyampaian materi, review dalam bentuk tanya jawab dan pemberian soal dapat meningkatkan prestasi belajar siswa dari $45 \%$ menjadi $100 \%$ pada siklus II dalam pembelajaran biologi di kelas VIII SMPN Satap Hoka.

\section{PENUTUP}

\section{Simpulan}

Penggunaan metode dan media bervariasi dapat memfasilitasi tercapainya tujuan pembelajaran biologi sesuai dengan karakteristik bidang ilmu \& tahap perkembangan siswa SMP, menghasilkan pembelajaran biologi yang menarik sebagai salah satu syarat untuk menumbuhkan minat siswa, dapat meningkatkan minat dan prestasi belajar siswa dalam pembelajaran biologi. Metode dan media bervariasi yang digunakan dalam pembelajaran biologi tingkat SMP dapat memfasilitasi siswa yang sedang berada pada tahap formal operational thought dan pemahaman romantik untuk mengembangkan kemampuan kognitif dan minatnya dalam mengeksplorasi kekayaan dan keutuhan dari biologi sebagai suatu ilmu pengetahuan. Penggunaan metode dan media yang variatif juga akan menghasilkan proses belajar yang menarik yang membantu siswa menemukan makna dari materi yang dipelajari sehingga semakin meningkatkan minat, pemahaman konsep, dan prestasi belajar mereka dalam pembelajaran biologi.

\section{Saran}

Penggunaan metode dan media bervariasi dalam pembelajaran biologi harus disesuaikan dengan topik yang diajarkan dan tingkat perkembangan siswa, namun tetap mempertimbangkan situasi, kondisi, dan fasilitas yang tersedia. Perlu dilakukan studi lanjut untuk mengetahui seberapa besar pengaruh metode dan media bervariasi terhadap minat, pemahaman konsep, dan prestasi belajar siswa.

\section{DAFTAR PUSTAKA}

Brahim, T.K., 2007. Peningkatan hasil belajar sains siswa kelas VI sekolah dasar melalui pendekatan pemanfaatan sumber daya alam hayati di lingkungan sekitar. Jurnal Pendidikan Penabur, 9, pp.37-49.

Van Brummelen, H., 2006. Berjalan bersama Tuhan di dalam kelas: Pendekatan Kristiani untuk pembelajaran [Walking with God in the classroom: Christian approaches in learning and teaching], Jakarta: Universitas Pelita Harapan.

Campbell, N.A., Reece, J.B. \& Mitchell, L.G., 2002. Biologi edisi kelima jilid I [Biology, fifth edition], Jakarta: Erlangga.

Depdikbud, 2016. Peraturan Menteri Pendidikan dan 
Kebudayaan Republik Indonesia Nomor 22 Tahun 2016 tentang Standar Proses Pendidikan Dasar dan Menengah, Jakarta: Depdikbud.

Depdiknas, 2007. Materi sosialisasi dan pelatihan Kurikulum Tingkat Satuan Pendidikan SMP, Jakarta: Depdiknas.

Depdiknas, 2003. Standar kompetensi mata pelajaran biologi SMA dan MA, Jakarta: Pusat Kurikulum, Balitbang Depdiknas.

Desmita, 2005. Psikologi Perkembangan, Bandung: PT Remaja Rosdakarya Offset (Rosda).

Djaali, H., 2007. Psikologi Pendidikan, Jakarta: Bumi Aksara.

Djamarah, S.B. \& Zain, A., 2006. Strategi Belajar Mengajar Edisi Revisi, Jakarta: PT Rineka Cipta.

Djiwandono, S.E. w., 2006. Psikologi Pendidikan Edisi Revisi, Jakarta: PT Gramedia Widiasarana Indonesia (Grasindo).

Hurlock, E., 2000. Perkembangan anak edisi 6 jilid II [Child development sixth edition], Jakarta: Erlangga.

Kusmiyati, 2007. Meningkatkan minat belajar IPA Biologi siswa sekolah menengah pertama. Jurnal Pijar MIPA, 2(2), pp.63-68. Available at: http://jurnal.pdii.lipi.go.id/index.php/Search. html? act $=$ tampil\&id $=9045$.

Muldayanti, N.D., 2013. Pembelajaran biologi model STAD dan TGT ditinjau dari keingintahuan dan minat belajar siswa. Jurnal Pendidikan IPA Indonesia, 2(1), pp.12-17.

Munadi, Y., 2008. Media Pembelajaran: Sebuah Pendekatan Baru, Jakarta: Gaung Persada Press.

Nuryani, 2005. Strategi Belajar Mengajar Biologi, Malang: Universitas Negeri Malang.

Pannen, P., Mustafa, D. \& Sekarwinahyu, M., 2001. Konstruktivisme dalam pembelajaran, Jakarta: Universitas Terbuka.

Prastati, T. \& Irawan, P., 2001. Media Sederhana, Jakarta: Universitas Terbuka.

Prastowo, A., 2012. Metode Penelitian Kualitatif dalam Prespektif Rancangan Penelitian, Yogyakarta: ArRuzz Media.

Rahmat, A., 2009. Super Teacher, Bandung: MQS Publishing.

Rizky, A., Pujiastuti \& Asyiah, I.N., 2015. Penerapan metode eksperimen dengan memanfaatkan media asli tumbuhan untuk meningkatkan aktivitas dan ketuntasan hasil belajar biologi (pokok bahasan klasifikasi makhluk hidup pada siswa kelas 7A di SMPN 2 Maesan Tahun Ajaran 2013/2014. Pancaran, 4(1), pp.79-88.

Sadiman, A.S. et al., 2005. Media Pendidikan, Jakarta:
PT RajaGrafindo Persada.

Sanjaya, W., 2006. Strategi pembelajaran berorientasi standar proses pendidikan, Jakarta: Kencana Prenada Media Group.

Santrock, J.W., 2003. Adolescence: Perkembangan Remaja edisi enam, Jakarta: Erlangga.

Sardiman, A.M., 2001. Interaksi dan Motivasi Belajar Mengajar, Jakarta: PT RajaGrafindo Persada.

Setiawan, P.Z. \& Napitupulu, E., 2014. Aplikasi media pembelajaran flipchart untuk meningkatkan penguasaan materi pertumbuhan dan perkembangan pada mata pelajaran IPA Teerpadu. Jurnal Teknologi Pendidikan, 7(2), pp.141-152.

Slameto, 2003. Belajar dan faktor-faktor yang mempengaruhinya edisi revisi, Jakarta: Rineka Cipta.

Suciati \& Irawan, P., 2001. Teori Belajar dan Motivasi, Jakarta: Universitas Terbuka.

Suherman, E., 2008. Model belajar dan pembelajaran berorientasi kompetensi siswa. Jurnal Educare, 5 (2). Available at: http://educare.ekipunla.net/index.php?option=com__ content $\&$ task=view\&id=60\&Itemid $=7$.

Susilonuringsih, K., 2006. Pengaruh faktor intern dan faktor ekstern terhadap minat belajar siswa kelas I di SMK Yayasan Pendidikan Ekonomi (YAPEK) Gomboong tahun diklat 2005/2006.

Sutikno, M.B., 2009. Belajar dan Pembelajaran: Upaya kreatif adalam mewujudkan pembelajaran yang berhasil, Bandung: Prospect.

Uzman, M.U., 2007. Menjadi Guru Professional, Bandung: PT Remaja Rosdakarya.

Yamin, H.M. \& Ansari, B.I., 2008. Taktik mengembangkan kemampuan individual siswa, Jakarta: Gaung Persada Press.

Zed, M., 2008. Metode Penelitian Kepustakaan, Jakarta: Yayasan Obor Indonesia. 